\title{
Seismic Evaluation of Fiber Reinforced Elastomeric Isolator with Different Irregularity Conditions in Building
}

\author{
Sreelakshmi K.S \\ Department of Civil Engineering \\ Sree Narayana Gurukulam College of Engineering \\ Ernakulam, India
}

\author{
Ananya John \\ Department of Civil Engineering \\ Sree Narayana Gurukulam College of Engineering \\ Ernakulam, India
}

\begin{abstract}
The growth in seismic isolation technology has led to the development of numerous innovative and unique base isolation devices. Fiber reinforced elastomeric isolators (FREIs) are low cost alternative to conventional steel reinforced elastomeric isolators (SREIs). FREIs are light in weight, easy to manufacture and cheaper than SRFIs. Fiber reinforced elastomeric isolators (FREIs) comprise alternating bonded layers of elastomer and fiber reinforcement sheets. A Partially Bonded Fiber Reinforced Elastomeric Isolator (PB-FREI) is achieved by partially bonding the top and bottom surfaces of the bearing to its contact supports. This study investigate the performance of partially bonded fiber reinforced elastomeric isolator under stiffness irregularity and mass irregularity conditions.
\end{abstract}

Keywords - Elastomeric isolator; mass irregularity; stiffness irregularity

\section{INTRODUCTION}

Fiber-reinforced elastomeric isolators (FREI) are a relatively recent development in the field of base isolation. The benefit of FREI is that they have the potential to be a lighter and less expensive alternative to current rubber isolation devices, such as low-damping rubber and lead-plug rubber isolators. Traditional isolators are comprised of layers of rubber and rigid steel shims that provide the bearing with vertical stiffness. By replacing the heavy, steel shims with lighter layers of fiber that have an elastic modulus similar to that of steel, studies indicate that FREI are able to satisfy vertical stiffness requirements for an isolator. In addition, the use of fiber as reinforcement introduces an additional flexural type response component into the isolator that affects its horizontal stiffness. Fiber reinforced elastomeric isolators (FREIs) comprise alternating bonded layers of elastomer and fiber reinforcement.

The prospect of a lighter and cheaper alternative to current rubber isolation devices prompted research into using FREI to isolate low rise masonry buildings and bridges. There are three types of application for fiber reinforced elastomeric isolators: Bonded FREI, Unbonded FREI and Partially Bonded FREI. In a bonded (B)-FREI, two thick steel mounting plates are bonded to the outer rubber layers at the top and bottom of the isolator. During installation, the top and bottom mounting plates are bolted to the superstructure and substructure, respectively. In a UB-FREI, the isolator is placed between the substructure and superstructure without any bonding or fastening provided at its contact surfaces. As such, the shear loads at the bearing contact surfaces are transferred through friction only. In a PB-application, only portions of the contact surfaces of the bearing are bonded to the upper and lower mounting plates. A significant amount of the tensile and shear forces can be transferred via the partial bond. The bearings were made from alternating layers of cold vulcanized Neoprene and carbon fiber fabric.

\section{OBJECTIVES}

- To investigate the performance of FREI under stiffness irregularity

- To study the behaviour of FREI under mass irregularity conditions

\section{SUMMARY OF LITERATURE REVIEW}

Fiber reinforced elastomeric bearings (FREB) comprise alternating bonded layers of elastomer and fiber reinforcement layers. A PB-FREB is achieved by partially bonding the top and bottom surfaces of the bearing to its contact supports. Studies were mainly carried out on the results of a comparative experimental study between UBFREB and PB-FREB. [1] A comparison of the seismic response of steel frames by using different types of bracing systems were mainly carried out. [2] FREI matches the behavior of an SREI, Consequently, the FREI could replace the conventional SREI for seismic isolation with low-cost manufacturing and lightweight installation. [3] By increasing the maximum imposed shear strain, the area of the isolator surfaces in contact with the concrete blocks decreases and, as a consequence, the isolator average horizontal stiffness also decreases. [4]

\section{NUMERICAL ANALYSIS}

The analytical study includes the development of finite element models to evaluate the performance of a partially bonded fiber reinforced elastomeric isolator with different irregularity conditions in a building. ANSYS workbench 16.1 software was used to perform the seismic evaluation of partially bonded fiber reinforced elastomeric isolator with different irregularity conditions in building.

\section{A. Material properties}

The material properties of the partially bonded fiber reinforced elastomeric isolator are tabulated in Table 1.

TABLE I. MATERIAL PROPERTIES

\begin{tabular}{|c|c|c|c|}
\hline $\begin{array}{c}\text { Element } \\
\text { type }\end{array}$ & Materials & $\begin{array}{c}\text { Modulus of } \\
\text { elasticity } \\
\text { (MPa) }\end{array}$ & $\begin{array}{c}\text { Poisons } \\
\text { Ratio }\end{array}$ \\
\hline $\begin{array}{c}\text { Beam 188 } \\
\text { and isolators } \\
\text { solid 186 }\end{array}$ & $\begin{array}{c}\text { Natural } \\
\text { rubber }\end{array}$ & 10 & 0.4 \\
\cline { 2 - 4 } & $\begin{array}{c}\text { Fiber } \\
\text { reinforcement }\end{array}$ & $1.37 \times 10^{5}$ & 0.2 \\
\cline { 2 - 4 } & Steel & $2 \times 10^{5}$ & 0.3 \\
\hline
\end{tabular}




\section{B. Base model}

ANSYS 16.1 workbench software was used to model the partially bonded fiber reinforced elastomeric isolator. Length and width of the partially bonded fiber reinforced elastomeric isolator was $100 \mathrm{~mm}$. A FREB pad of $100 \times 100 \mathrm{~mm}$ comprised of 4 inner layers of elastomer of $4.5 \mathrm{~mm}$ thickness, and two outer layers of $2.5 \mathrm{~mm}$ thickness is modelled. The total height of the isolators is approximately $25.5 \mathrm{~mm}$. The total thickness of the rubber layers is $\operatorname{tr}=23 \mathrm{~mm}$. The shape factor of the isolators is $\mathrm{S} 1=5.56$. The aspect ratio is approximately $\mathrm{S} 2=3.92$. The elastomeric laminated rubber isolators, a cover rubber layer is bonded along the perimeter of each isolator to provide protection against oxygen and ozone attacks. Two square end steel plates of $100 \mathrm{~mm}$ width are partially bonded across an area of $50 \times 50 \mathrm{~mm}$ at the center of the outer elastomer layers. Fig 1 presents the isometric view of partially bonded fiber reinforced elastomeric isolator.

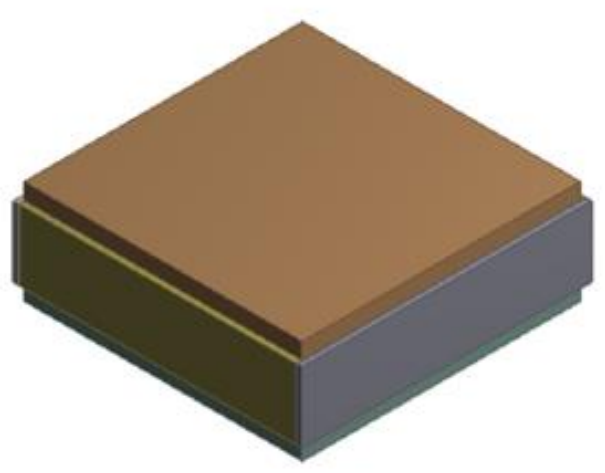

Fig. 1. Partially bonded fiber reinforced elastomeric isolator

The specimen is placed in the four storey building and three storey building. The plan of the building is selected as per Dia Eddin Nassani et al. [2]. The front view of the four storey and three storey are shown in the Fig 2. The total height of the four storey building is $16.47 \mathrm{~m}$ and the height of the three storey building is $12.81 \mathrm{~m}$.

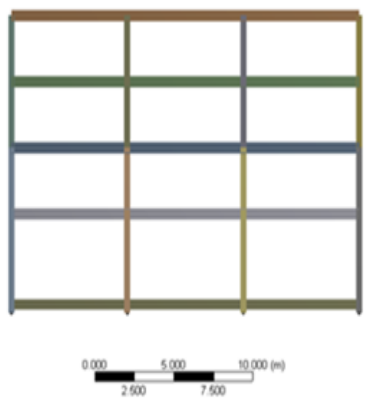

a)
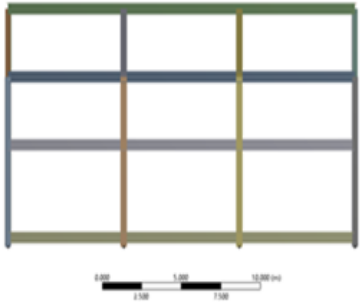

b)
Fig. 2 Front view of buildings a) 4 storey building b) 3 storey building

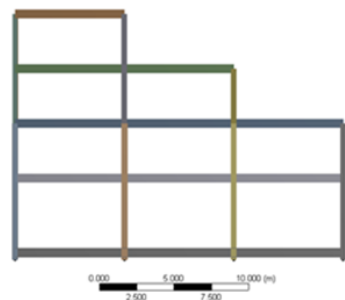

a)

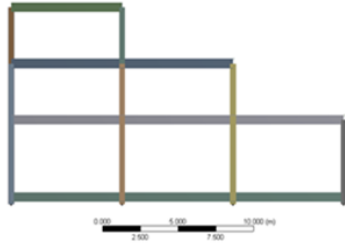

c)

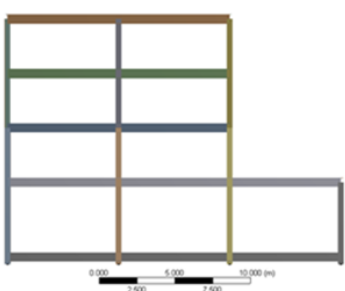

b)

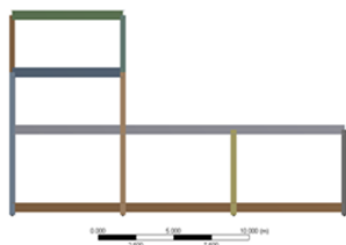

d)
Fig. 3. Stiffness irregularities of buildings a) 4 storey stiffness irregularity 1 b) 4 storey stiffness irregularity 2 c) 3 storey stiffness irregularity 1 d) 3 storey stiffness irregularity 2

The PB-FREI is placed in the four storey building and load is distributed in all floors (4S). Top storey of the four storey building is unloaded and the other three floors are loaded (4S MIR@4). Then the third floor is unloaded and remaining floors are loaded (4S MIR@3). Similarly the second (4S MIR@2) and first floor (4S MIR@1) is unloaded and remaining floors are loaded. Similarly the three storey building mass irregularity is also considered. Two stiffness irregularity conditions in four storey and three storey building are shown in Fig 3.

\section{RESULTS AND DISCUSSIONS}

The results of numerical analysis such as isolation displacement, top storey displacement and shear stress on corner, exterior and interior under mass irregularity is shown in Table II. The storey displacement graph of 4 storey and 3 storey mass irregularity are shown in Fig.4. The storey displacement graph of 4 storey and 3 storey stiffness irregularities are shown in Fig.5. The results of PB-FREI with stiffness irregularity is shown in Table III.

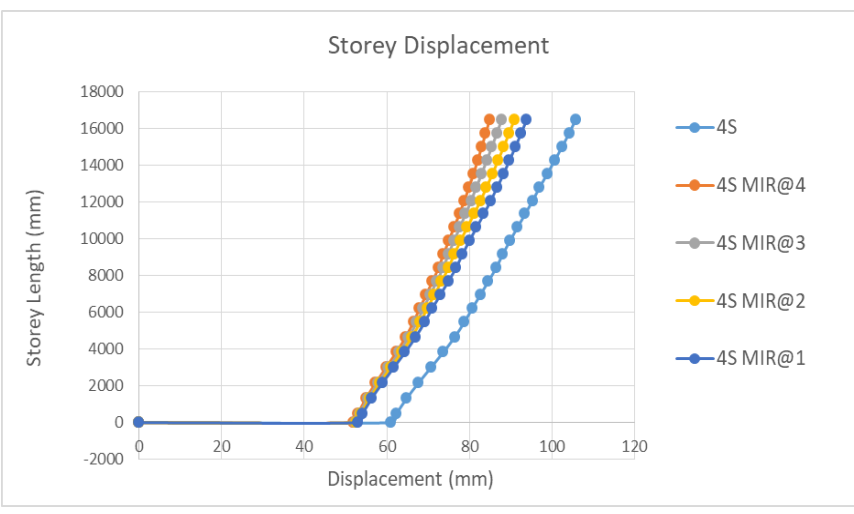

a) 


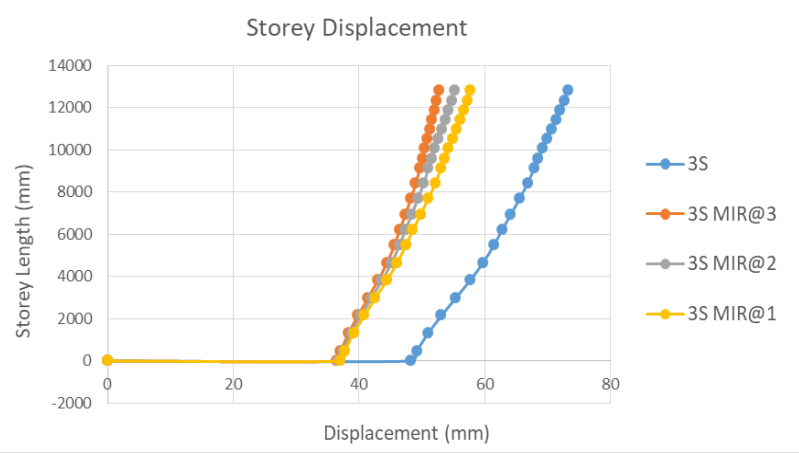

b)

Fig. 4. Storey Displacement graph a) 4 storey mass irregularity b) 3 storey mass irregularity

From the storey displacement analysis as shown in fig 4 , it is observed that the displacement is increases with increase in storey length. The diaplacement is maximum at the top of the building. The results of partially bonded fiber reinforced elastomeric isolator with mass irregularity is shown in Table II. The shear stress is maximum at the isolators on corner and shear stress on exterior is minimum.

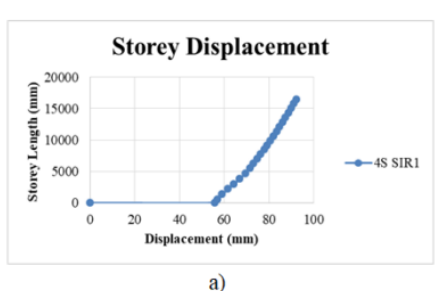

a)

c)

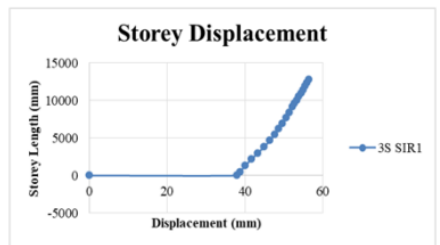

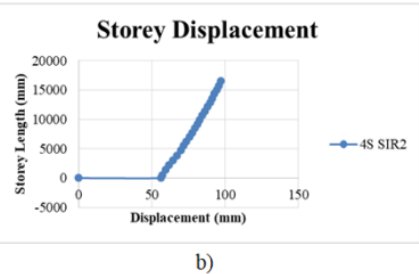

b)

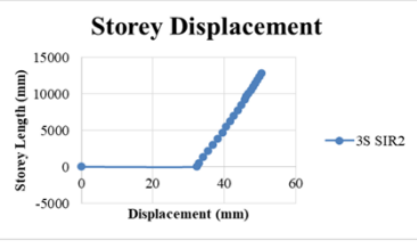

d)
Fig. 5. Storey Displacement graph a) 4 storey stiffness irregularity 1 (4S SIR1) b) 4 storey irregularity irregularity 2 (4S SIR2) c) 3 storey stiffness irregularity 1 (3S SIR1) d) 3 storey stiffness irregularity 2 (3S SIR2)

TABLE II. COMPARISON OF RESULTS OF PB-FREI WITH MASS IRREGULARITY

\begin{tabular}{|l|l|l|l|l|l|}
\hline $\begin{array}{l}\text { Model } \\
\text { name }\end{array}$ & $\begin{array}{l}\text { Isolation } \\
\text { Displacement }\end{array}$ & $\begin{array}{l}\text { Top storey } \\
\text { Displacement }\end{array}$ & $\begin{array}{l}\text { Shear } \\
\text { stress } \\
\text { on } \\
\text { corner }\end{array}$ & $\begin{array}{l}\text { Shear } \\
\text { stress } \\
\text { on } \\
\text { Exterior }\end{array}$ & $\begin{array}{l}\text { Shear } \\
\text { stress } \\
\text { on } \\
\text { interior }\end{array}$ \\
\hline 4S & 61.055 & 105.72 & 418.22 & 174.31 & 188.13 \\
\hline $\begin{array}{l}4 S \\
\text { MIR@4 }\end{array}$ & 51.993 & 84.904 & 332.21 & 152.54 & 161.7 \\
\hline $\begin{array}{l}\text { 4S } \\
\text { MIR@3 }\end{array}$ & 52.292 & 87.778 & 351.45 & 152.14 & 161.1 \\
\hline
\end{tabular}

\begin{tabular}{|l|l|l|l|l|l|}
\hline $\begin{array}{l}\text { 4S } \\
\text { MIR@2 }\end{array}$ & 52.621 & 90.85 & 370.84 & 151.8 & 160.46 \\
\hline $\begin{array}{l}4 S \\
\text { MIR@1 }\end{array}$ & 52.981 & 93.845 & 390.11 & 151.47 & 159.81 \\
\hline 3S & 48.315 & 73.264 & 291.78 & 140.96 & 152.05 \\
\hline $\begin{array}{l}3 \mathrm{~S} \\
\text { MIR@3 }\end{array}$ & 36.47 & 52.759 & 201.26 & 108.55 & 116.63 \\
\hline $\begin{array}{l}3 S \\
\text { MIR@2 }\end{array}$ & 36.725 & 55.222 & 220.23 & 108.18 & 116.03 \\
\hline $\begin{array}{l}3 S \\
\text { MIR@1 }\end{array}$ & 37.023 & 57.798 & 239.18 & 107.84 & 115.41 \\
\hline
\end{tabular}

TABLE III. COMPARISON OF RESULTS OF PB-FREI WITH STIFFNESS IRREGULARITY

\begin{tabular}{|l|l|l|l|l|l|}
\hline $\begin{array}{l}\text { Model } \\
\text { name }\end{array}$ & $\begin{array}{l}\text { Isolation } \\
\text { Displacement }\end{array}$ & $\begin{array}{l}\text { Top storey } \\
\text { Displacement }\end{array}$ & $\begin{array}{l}\text { Shear } \\
\text { stress } \\
\text { on } \\
\text { corner }\end{array}$ & $\begin{array}{l}\text { Shear } \\
\text { stress } \\
\text { on } \\
\text { Exterior }\end{array}$ & $\begin{array}{l}\text { Shear } \\
\text { stress } \\
\text { on } \\
\text { interior }\end{array}$ \\
\hline $\begin{array}{l}\text { 4S } \\
\text { SIR1 }\end{array}$ & 55.923 & 92.404 & 355.86 & 160.62 & 174.76 \\
\hline $\begin{array}{l}4 S \\
\text { SIR2 }\end{array}$ & 56.283 & 97.152 & 386.1 & 160.62 & 172.08 \\
\hline $\begin{array}{l}\text { 3S } \\
\text { SIR1 }\end{array}$ & 38.039 & 56.462 & 214.36 & 111.39 & 122.14 \\
\hline $\begin{array}{l}\text { 3S } \\
\text { SIR2 }\end{array}$ & 32.415 & 50.436 & 186.68 & 95.426 & 105.13 \\
\hline
\end{tabular}

\section{CONCLUSIONS}

In the present study, partially bonded fiber reinforced elastomeric isolator were introduced in the building and the behaviour of PB-FREI under mass irregularity conditions were studied. Four storey building and three storey building were considered. Further the performance of PB-FREI under stiffness irregularity conditions were also studied. From the result obtained from this paper it can be concluded as follows:

- The displacement is maximum at the top storey of the building

- The top storey displacement is more than the isolation displacement.

- Shear stress is maximum at the isolators on corner and shear stress is minimum at the isolators on exterior.

\section{REFERENCES}

[1] H. Toopchi-Nezhad, M.R. Ghotb, Y.M. Al-Anany and M.J. Tait (2019), "Partially bonded fiber reinforced elastomeric bearings: Feasibility, effectiveness, aging effects, and low temperature response", Engineering Structures 179 (2019) 120-128

[2] Dia Eddin Nassani, Ali Khalid Hussein and Abbas Haraj Moham-med (2017), "Comparative Response Assessment of Steel Frames With Different Bracing Systems Under Seismic Effect”, Structures 11 (2017) 229-242

[3] Byung-Young Moon, Gyung-Ju Kang, Beom-Soo Kang, James M. Kelly (2002), "Design and manufacturing of fiber reinforced elastomeric isolator for seismic isolation", Journal of Materials Processing Technology, Elsevier, 130-131, 145-150

[4] Gaetano Russo, Margherita Pauletta, Andrea Cortesia (2013), “A study on experimental shear behavior of fiber-reinforced elastomeric isolators with various fiber layouts, elastomers and aging conditions", Engineering Structures, Elsevier, 52, 422-433 